\title{
Unexpected lack of specificity of a rabbit polyclonal TAP-L
}

\section{(ABCB9) antibody [version 1; peer review: 1 approved, 2}

\section{approved with reservations]}

\author{
Peter van Endert1-3, Myriam Lawand ${ }^{1-3}$ \\ ${ }^{1}$ Institut National de la Santé et de la Recherche Médicale (INSERM) U1151, Paris, 75015, France \\ ${ }^{2}$ Centre national de la recherche scientifique (CNRS), Unité mixte de recherche (UMR) 8253, Paris, 75015, France \\ 3Université Paris Descartes, Sorbonne Paris Cité, 75015, France
}

V1 First published: 22 May 2015, 4:125

https://doi.org/10.12688/f1000research.6535.1

Latest published: 22 May 2015, 4:125

https://doi.org/10.12688/f1000research.6535.1

\section{Abstract}

In this article, we describe the surprising non-specific reactivity in immunoblots of a rabbit polyclonal antibody (ref. Abcam 86222) expected to recognize the transporter associated with antigen processing like (TAP-L, ABCB9) protein. Although this antibody, according to company documentation, recognizes a band with the expected molecular weight of $84 \mathrm{kDa}$ in HeLa, 293T and mouse NIH3T3 whole-cell lysates, we found that this band is also present in immunoblots of TAP-L deficient bone marrow-derived dendritic cell (BMDC) whole-cell lysates in three independent replicates. We performed extensive verification by multiple PCR tests to confirm the complete absence of the ABCB9 gene in our TAP-L deficient mice. We conclude that the antibody tested cross-reacts with an unidentified protein present in TAP-L knockout cells, which coincidentally runs at the same molecular weight as TAP-L. These findings underline the pitfalls of antibody specificity testing in the absence of cells lacking expression of the target protein.

\section{Keywords}

ABCB9, TAP-L transporter, dendritic cell, antigen presentation, MHC, peptide, lysosome

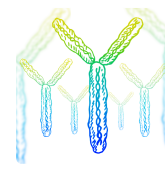

This article is included in the Antibody

Validations gateway.

\section{Open Peer Review

\begin{tabular}{cccc} 
Approval Status & $? ?$ \\
& 1 & 2 & 3 \\
\hdashline & $?$ & $?$ & \\
version 1 & $?$ & view & view \\
22 May 2015 & view &
\end{tabular} \\ 1. James Drake Al Albany Medical College, Albany, USA \\ 2. Frank Momburg, German Cancer Research Center, Heidelberg, Germany \\ 3. Malini Raghavan ID, University of Michigan Medical School, MI, USA \\ Any reports and responses or comments on the article can be found at the end of the article.}


Corresponding author: Peter van Endert (peter.van-endert@inserm.fr)

Competing interests: Both authors confirm that they have no conflict of interest.

Grant information: Supported by a grant from the Fondation pour la Recherche Médicale (Equipe FRM DEQ20130326539) to PVE.

Copyright: @ 2015 van Endert P and Lawand M. This is an open access article distributed under the terms of the Creative Commons Attribution License, which permits unrestricted use, distribution, and reproduction in any medium, provided the original work is properly cited.

How to cite this article: van Endert $P$ and Lawand M. Unexpected lack of specificity of a rabbit polyclonal TAP-L (ABCB9) antibody [version 1; peer review: 1 approved, 2 approved with reservations] F1000Research 2015, 4:125 https://doi.org/10.12688/f1000research.6535.1

First published: 22 May 2015, 4:125 https://doi.org/10.12688/f1000research.6535.1 


\section{Introduction}

TAP-L (TAP-Like), also known as ABCB9, is an ATP-dependent membrane half-transporter. It belongs, like TAP, the transporter associated with antigen processing, to the $\mathrm{ABC}$ transporter family, the members of which transport various molecules across membranes. TAP-L can form homodimers and is located primarily in lysosomes, presumably importing peptides from the cytosol. TAP-L has broad specificity for peptides ranging from a length of 6 to 59 amino acids, with an optimal activity for peptides of 23 residues (Wolters et al., 2005). TAP-L can transport two peptides at a time (Herget et al., 2009). Considering its similarity to the heterodimeric TAP transporters (ABCB2/3) importing MHC class I peptide ligands into the endoplasmic reticulum, TAP-L is a potential candidate involved in antigen presentation by MHC molecules (Bangert et al., 2011). Indeed, the length of the peptides transported by TAP-L (6-59 residues) is compatible with loading of both MHC class I and class II molecules. Moreover, TAP-L is highly expressed in lysosomes of professional antigen presenting cell (APC) lysosomes, and upregulated during differentiation of dendritic cells. However, such a function remains hypothetical, and the biological role of TAP-L is presently unknown.

In this article, we describe experimentation designed to specifically detect the ABCB9 protein in bone marrow-derived dendritic cells (BMDCs) by immunoblot. We purchased a rabbit polyclonal antibody generated by Abcam Company using a synthetic peptide as the immunogen, corresponding to a region between residues 475 and 525 of human ABCB9. This antibody is expected to recognize mouse and human $\mathrm{ABCB} 9$ and recommended for immunohistochemistry (IHC), immunoprecipitation (IP) and western blot (WB).

\section{Materials and methods \\ Mice}

C57/BL6 TAP-L KO/WT heterozygous mice (ABCB9 ${ }^{\mathrm{tm} 1 \text { (КомP) Vlcg }}$ ) were purchased from The Komp Repository at the University of California at Davis, CA 95616 (see the results section for details). Heterozygous mice were bred in our laboratory and inter-crossed to obtain homozygous knock out (KO) mice (TAP-L KO/KO) along with their C57/BL6 wild type (WT) littermates.

\section{BMDC culture}

Bone Marrow-derived Dendritic Cells (BMDCs) were generated from precursors isolated from femur and tibia of C57/BL6 WT and TAP-L KO mice and cultured for 6 days in IMDM (Iscove's Modified Dulbecco's Medium) (Sigma Aldrich, St. Quentin Fallavier, France) supplemented with $10 \%$ fetal calf serum (FCS), $2 \mathrm{mM}$ L-glutamine (PAA, Velizy-Villacoublay, France), $100 \mathrm{U} / \mathrm{ml}$ penicillin, $100 \mu \mathrm{g} / \mathrm{ml}$ streptomycin (PAA), and $50 \mu \mathrm{M}$ 2-mercaptoethanol
(GIBCO, Cergy Pontoise, France) in the presence of 3\% supernatant of J558 hybridoma cells producing GM-CSF (Granulocytemacrophage colony-stimulating factor) (Inaba et al., 1992).

\section{Sample preparation}

On day 6 of culture, WT and TAP-L KO BMDCs (Table 1) were lysed in a buffer containing $20 \mathrm{mM}$ Tris- $\mathrm{HCl} \mathrm{pH} 7.4,150 \mathrm{mM} \mathrm{NaCl}$, $5 \mathrm{mM} \mathrm{MgCl}, 1 \% \mathrm{NP} 40$ and protease inhibitors (protease inhibitor cocktail, Roche) for $1 \mathrm{~h}$ at $4^{\circ} \mathrm{C}$. Protein concentration was determined by Lowry's method, a biochemical assay for determining the total level of protein in a solution, using DC Protein Assay Reagents Package $^{\mathrm{TM}}$ (BioRad).

Twenty to $200 \mu \mathrm{g}$ protein from total cell lysate was mixed at a volume ratio of 1:1 with $2 x$ Laemmli buffer containing $62.5 \mathrm{~mm}$ Tris$\mathrm{HCl} \mathrm{pH} 6.8,25 \%$ glycerol, $2 \%$ SDS, $0.01 \%$ bromophenol blue, $100 \mathrm{mM}$ DTT and heated for $10 \mathrm{~min}$ at $95^{\circ} \mathrm{C}$.

\section{Electrophoresis and western blot (WB)}

Reagents are listed in Table 2 and Table 3 and the WB protocol is given in Table 4 . The samples were loaded on a $10 \%$ acrylamide gel for electrophoresis at $80 \mathrm{~V}$. Separated proteins were transferred onto polyvinylidine fluoride (PVDF) membrane (pore size $0.4 \mu \mathrm{m}$ ) for $1 \mathrm{~h}$ at $75 \mathrm{~V}$. The membrane was blocked with $5 \%$ BSA (Bovine Serum Albumin) in Tris-Buffered Saline $(50 \mathrm{mM}$ Tris, $150 \mathrm{mM}$ $\mathrm{NaCl}$ ) containing $0.5 \%$ Tween 20 (TBS-T) for $1 \mathrm{~h}$ at room temperature, then incubated with the polyclonal rabbit ABCB9 antibody (Abcam, Catalog number 86222, Lot number: GR22408-1) diluted $1 / 2000$ in TBS-T with $5 \%$ BSA for $1 \mathrm{~h}$ at room temperature. The membrane was washed four times for 5 min with TBS-T then incubated with a goat polyclonal anti-Rabbit-HRP (Jackson ImmunoResearch Laboratory; Suffolk, UK) secondary antibody diluted 1/5000 in TBS-Tween 5\% BSA for $1 \mathrm{~h}$ at room temperature. An enhanced chemiluminescence (ECL) detection system, Immobilon Western HRP (Millipore, Guyancourt, France) was used for developing the membranes. Images were taken with a CCD camera (Fujifilm, Tokyo, Japan). Three independent experiments were performed.

\section{Results}

Seeking to detect the ABCB9 protein, we performed a series of WBs on whole-cell lysates obtained from BMDCs, thought to correspond to an inflammatory subtype of DCs. It has previously been shown that $\mathrm{ABCB} 9$ expression by monocyte-derived human DCs is increased under inflammatory conditions (Demirel et al., 2007). To validate specificity of antibody staining, we included TAP-L deficient BMDCs as a negative control. TAP-L KO/WT heterozygous mice (ABCB9 $9^{\mathrm{ml} 1}$ (KOMP) Vlcg $)$, in which the region located between nucleotides 5625 and 33216 of the TAP-L gene has been

Table 1. Cells used during the validation assay.

\begin{tabular}{|l|l|l|l|l|}
\hline Species & Tissue Type & Strain/Cell line & RRID & Details \\
\hline Murine & BMDCs & C57/BL6 WT mouse & RRID:MGI_2439598 & Female/Male \\
\hline Murine & BMDCs & C57/BL6 TAP-L KO mouse & RRID:MGI_5636449 & Female/Male \\
\hline
\end{tabular}


Table 2. Reagents used for WB analysis.

\begin{tabular}{|c|c|c|c|c|}
\hline Process & Reagent & Manufacturer & $\begin{array}{l}\text { Catalogue } \\
\text { number }\end{array}$ & Concentration/Composition \\
\hline \multirow{3}{*}{$\begin{array}{l}\text { Sample } \\
\text { preparation }\end{array}$} & Lysis Buffer & Homemade & & $\begin{array}{l}20 \mathrm{mM} \text { Tris- } \mathrm{HCl} \mathrm{pH} 7.4,150 \mathrm{mM} \\
\mathrm{NaCl}, 5 \mathrm{mM} \mathrm{MgCl}, 1 \% \mathrm{NP} 40\end{array}$ \\
\hline & $\begin{array}{l}\text { DC Protein Assay } \\
\text { Reagents Package }\end{array}$ & BioRad & $500-0116$ & \\
\hline & Laemmli Buffer 2x & Homemade & & $\begin{array}{l}62.5 \mathrm{~mm} \text { Tris- } \mathrm{HCl} \mathrm{pH} 6.8,25 \% \\
\text { glycerol, } 2 \% \text { SDS, } 0.01 \% \\
\text { bromophenol blue, } 100 \mathrm{mM} \text { DTT }\end{array}$ \\
\hline Staining & $\begin{array}{l}\text { ECL detection } \\
\text { system, Immobilon } \\
\text { Western HRP }\end{array}$ & Millipore & WBKLS0500 & \\
\hline \multirow{4}{*}{ Washes/Blocks } & Washing Buffer & Homemade & & $\begin{array}{l}\text { TBS-T: Tris-Buffered Saline } \\
\text { (50mM Tris, } 150 \mathrm{mM} \mathrm{NaCl)} \\
\text { containing } 0.5 \% \text { Tween } 20\end{array}$ \\
\hline & Tween 20 & Sigma Aldrich & P1379 & \\
\hline & Blocking buffer & Homemade & & TBS-T with 5\% BSA \\
\hline & BSA & Sigma Aldrich & A7906 & \\
\hline \multirow{3}{*}{$\begin{array}{l}\text { Electrophoresis } \\
\text { and protein } \\
\text { transfer }\end{array}$} & Acrylamide gel $10 \%$ & Homemade & & \\
\hline & Running Buffer & Homemade & & $\begin{array}{l}25 \mathrm{mM} \text { Tris, } 192 \mathrm{mM} \text { glycine, } \\
0.1 \% \text { SDS }\end{array}$ \\
\hline & Transfer Buffer & Homemade & & $\begin{array}{l}\text { 10mM CAPS (pH11), 10\% } \\
\text { Methanol }\end{array}$ \\
\hline
\end{tabular}

Table 3. Primary and secondary antibodies.

\begin{tabular}{|l|l|l|l|l|}
\hline Antibody & Manufacturer & Catalogue number & RRID & Concentration \\
\hline $\begin{array}{l}\text { Rabbit polyclonal } \\
\text { anti-ABCB9 }\end{array}$ & Abcam & 86222 & RRID:AB_1924743 & $1 / 2000$ \\
\hline $\begin{array}{l}\text { Goat polyclonal } \\
\text { anti-Rabbit-HRP }\end{array}$ & $\begin{array}{l}\text { Jackson } \\
\text { Immunoresearch }\end{array}$ & $111-035-003$ & RRID:AB_2313567 & $1 / 5000$ \\
\hline
\end{tabular}

\begin{tabular}{|c|c|c|c|}
\hline Protocol steps & Reagent & Time & Temperature \\
\hline \multirow{2}{*}{ Sample preparation } & Lysis Buffer & $1 \mathrm{~h}$ & $4^{\circ} \mathrm{C}$ \\
\hline & Laemmli Buffer 2x & $10 \mathrm{~min}$ & $95^{\circ} \mathrm{C}$ \\
\hline \multirow{2}{*}{ Electrophoresis (80V) } & Acrylamide gel $10 \%$ & \multirow[t]{2}{*}{$1 \mathrm{~h}$} & \multirow{2}{*}{$\begin{array}{l}\text { Room } \\
\text { temperature }\end{array}$} \\
\hline & Running Buffer & & \\
\hline \multirow{2}{*}{ Protein transfer $(75 \mathrm{~V})$} & PVDF membrane (pore size $0.4 \mu \mathrm{m}$ ) & \multirow{2}{*}{$1 \mathrm{~h}$} & \multirow{2}{*}{$4^{\circ} \mathrm{C}$} \\
\hline & Transfer Buffer & & \\
\hline Blocking & TBS-T 5\% BSA & $1 \mathrm{~h}$ & $\begin{array}{l}\text { Room } \\
\text { temperature }\end{array}$ \\
\hline Primary antibody & Rabbit anti-ABCB9 & $1 \mathrm{~h}$ & $\begin{array}{l}\text { Room } \\
\text { temperature }\end{array}$ \\
\hline Washes (4 times) & TBS-T & 5 min each & $\begin{array}{l}\text { Room } \\
\text { temperature }\end{array}$ \\
\hline Secondary antibody & Goat anti-Rabbit-HRP & $1 \mathrm{~h}$ & $\begin{array}{l}\text { Room } \\
\text { temperature }\end{array}$ \\
\hline Washes (4 times) & TBS-T & 5 min each & $\begin{array}{l}\text { Room } \\
\text { temperature }\end{array}$ \\
\hline Detection & ECL detection system & 20 seconds & $\begin{array}{l}\text { Room } \\
\text { temperature }\end{array}$ \\
\hline
\end{tabular}


removed for the insertion of a cassette of $6085 \mathrm{bp}$ containing the cDNA conferring resistance to neomycin $(\mathrm{Neo})$, were purchased from The Komp Repository at the University of California at Davis, CA 95616 (see construction of the KO gene; Figure 2A). Heterozygous mice were bred in our laboratory and inter-crossed to obtain homozygous KO mice (TAP-L KO/KO). To our surprise, the ABCB9 antibody recognized a band, with an apparent molecular weight $(84 \mathrm{kDa})$ corresponding to that of $\mathrm{ABCB} 9$ protein, both in WT and TAP-L deficient BMDCs (Figure 1). Three different immunoblots were performed in three independent experiments.

Given these surprising results, we verified that the TAP-L KO mice were truly deficient for the target gene. We performed a series of polymerase chain reactions (PCRs). Different fragments of the WT allele (located in exons 2, 4, 8, 11 and introns 5, 6, 9) and the expected genomic region in $\mathrm{KO}$ mice (located between the upstream or downstream arm and within the Neo cassette) were amplified by PCR.

The following forward $(\mathrm{F})$ and reverse $(\mathrm{R})$ primers were used:

- Ex1-F: 5'-GTAGTAGTGACGCTGGCCTT-3' and Ex1-R: 5'CTTCTGTAGTGTGGCTCCCG-3', located in exon 1 of the WT allele and amplifying a product of 498bp in the WT allele

- Ex2-F: 5'-AGACCTTCCTGCCCTACTACA-3' and Ex2-R: 5'-CAGCAGGCAAACGACGACAA-3', located in exon 2 of the WT allele and amplifying a product of $101 \mathrm{bp}$ in the WT allele

- Ex4-F: 5'-CGCCTCACCTCTGATACCAC-3' and Ex4-R: 5'-TGCCGTAGATGTTGGACACC-3', located in exon 4 of the WT allele and amplifying a product of $181 \mathrm{bp}$ in the WT allele
- Ex8-F: 5'-CAAGGTGACAGCTCTGGTGG-3' and Ex8-R: 5'-GCCATCCAACAATACACGGC-3', located in exon 8 of the WT allele and amplifying a product of 106bp in the WT allele

- Ex11-F: 5'-GAGACACACGGTGCTCATCA-3' and Ex11-R: 5'-TGTGTTCAGTGTTGCTGGGT-3', located in exon 11 of the WT allele and amplifying a product of $214 \mathrm{bp}$ in the WT allele

- INT5-F: 5'-TACTCGGGTGCCACTACCTG-3' and INT5-R: 5'-GGCACATGCCACCTTCAAGT-3', located in intron 5 of the WT allele and amplifying a product of $379 \mathrm{bp}$ in the WT allele

- INT6-F: 5'-TGCTTAAAGGCACTCGGTGA-3' and INT6-R: 5'-CTTCGGGGATACCACAGAGC-3', located in intron 6 of the WT allele and can amplifying a product of $371 \mathrm{bp}$ in the WT allele

- INT9-F: 5'-TGCCAAGTTTAGTGCCAGGATG-3' and INT9-R: 5'-GCCCAGGACAAAAAAAGCAATC-3', located in the intron 9 of the WT allele and amplifying a product of $371 \mathrm{bp}$ in the WT allele

- KOFwd1: 5'-TTGCATGGAGAAGACCCTCC-3', located in the arm upstream of the Neo cassette (Neo upstream arm), and KORvs1: 5'-GAGGGGACGACGACAGTATC-3', located in the Neo cassette and amplifying a product of $465 \mathrm{bp}$ in the $\mathrm{KO}$ allele

- KOFwd2: 5'-GCAGCCTCTGTTCCACATACACTTCA-3', located in the Neo cassette and KORvs2: 5'-GCTTAGTTCTCTCCCAGACATCCTCC-3', located in the arm downstream of the Neo cassette (Neo downstream arm) and amplifying 425bp in the KO allele.

PCRs were performed in a total volume of $25 \mu$ containing: 17.3 $\mu \mathrm{l} \mathrm{H2O}$ (DEPC treated water, pathogen free, DNase/RNase

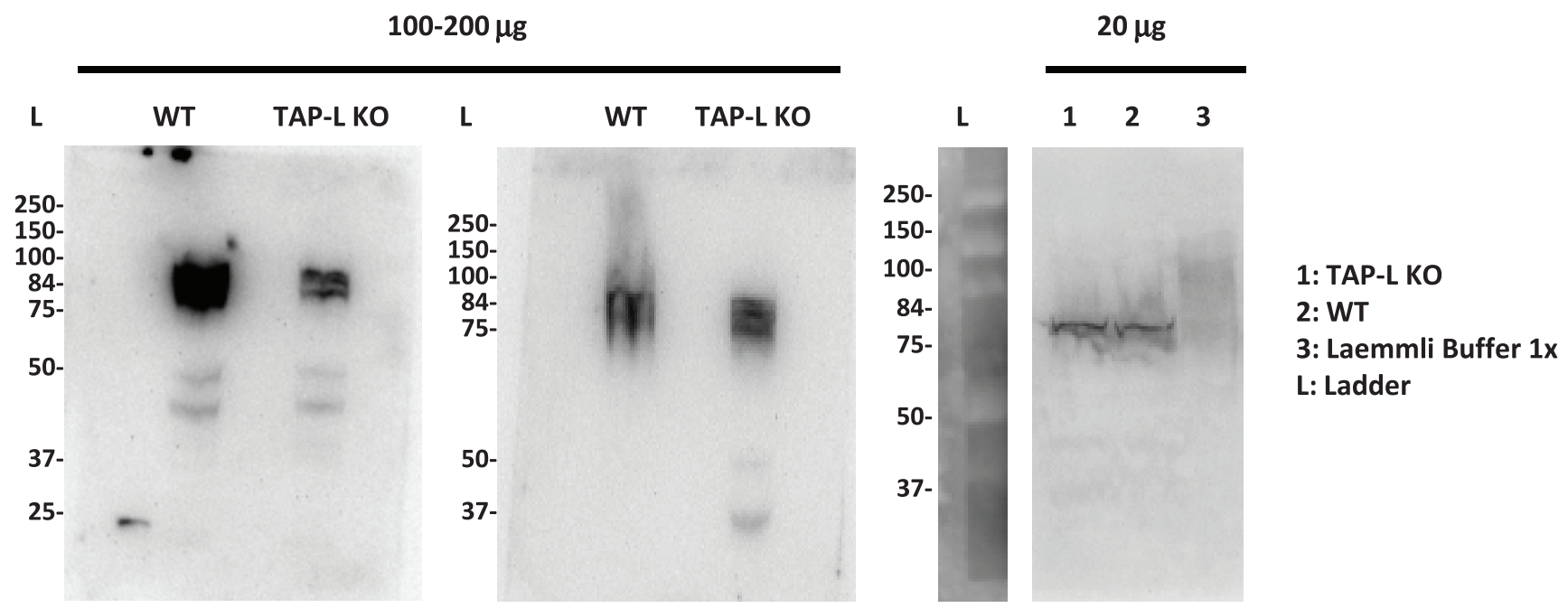

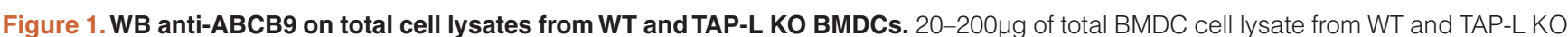
BMDCs was loaded on $10 \%$ acrylamide gels. The proteins were transferred onto a PVDF membrane. The rabbit ABCB9 antibody was used to detect the TAP-L protein (84kDa), followed by incubation with an HRP-conjugated goat anti-rabbit secondary antibody. An ECL detection system was used for developing the membranes by chemoluminescence. Three immunoblots from three independent experiments are shown. 


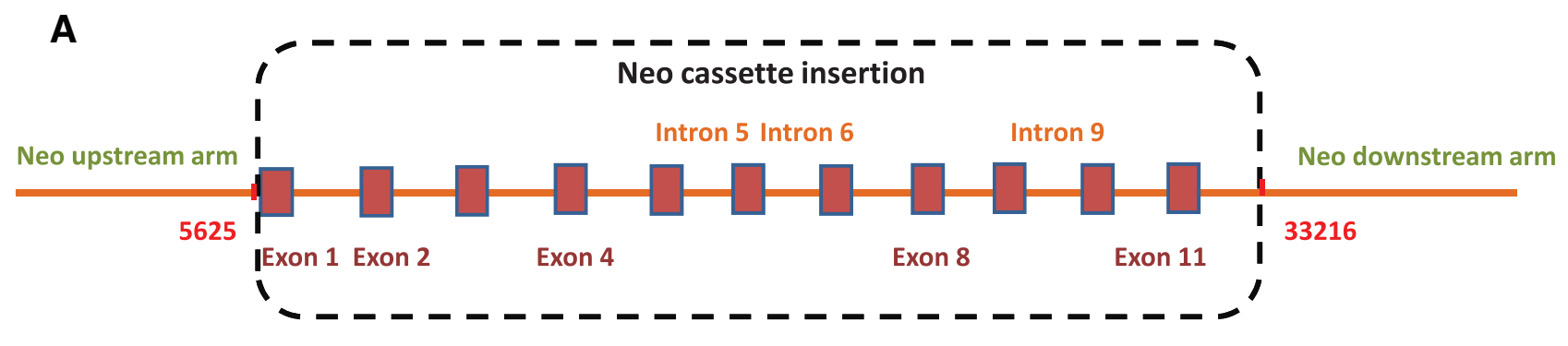

B
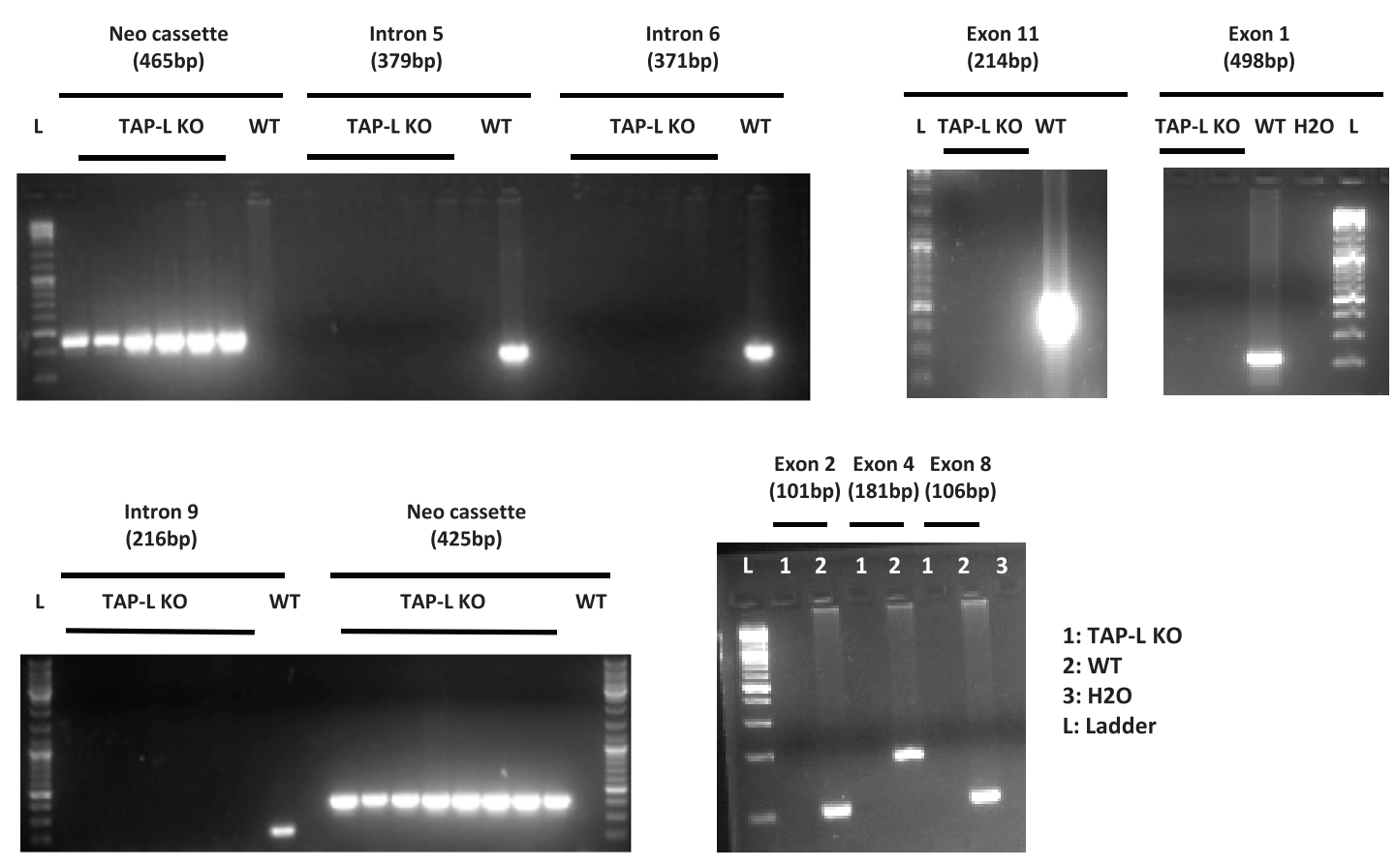

Figure 2. Strategy for genomic invalidation of the TAP-L/ABCB9 gene (A) and genotyping of WT and TAP-L deficient mice (B). In B, multiple $\mathrm{KO}$ mice were tested in the PCRs amplifying the Neo cassette and introns 5, 6 and 9. L, DNA ladder (See the results section for details).

Free-Invitrogen), $5 \mu \mathrm{l}$ x GoTaq Green Reaction Buffer (Promega), $0.5 \mu \mathrm{l}$ dNTP $(10 \mathrm{mM}), 20 \mu \mathrm{M}$ primers, $0.2 \mu$ l polymerase $(5 \mathrm{U} / \mu \mathrm{l})$ (GoTaq-Promega polymerase) and $1 \mu \mathrm{l}$ DNA or water (negative control). The amplification reaction was performed as follows: for the WT allele, an initial denaturation at $94^{\circ} \mathrm{C}$ for $5 \mathrm{~min}, 10$ cycles: denaturation $94^{\circ} \mathrm{C}$ for $15 \mathrm{sec}$, annealing $65^{\circ} \mathrm{C}$ for $30 \mathrm{sec}$, elongation $72^{\circ} \mathrm{C}$ for $40 \mathrm{sec} ; 30$ cycles denaturation $94^{\circ} \mathrm{C}$ for $15 \mathrm{sec}$, annealing $55^{\circ} \mathrm{C}$ for $30 \mathrm{sec}$, elongation $72^{\circ} \mathrm{C}$ for $40 \mathrm{sec}$; final elongation $72^{\circ} \mathrm{C}$ for $5 \mathrm{~min}$. For the $\mathrm{KO}$ allele: initial denaturation at $94^{\circ} \mathrm{C}$ for $5 \mathrm{~min}$; 10 cycles: denaturation $94^{\circ} \mathrm{C}$ for $15 \mathrm{sec}$, annealing $62^{\circ} \mathrm{C}$ for $30 \mathrm{sec}$, elongation $72^{\circ} \mathrm{C}$ for $40 \mathrm{sec} ; 25$ cycles: denaturation $94^{\circ} \mathrm{C}$ for $15 \mathrm{sec}$, annealing $57^{\circ} \mathrm{C}$ for $30 \mathrm{sec}$, elongation $72^{\circ} \mathrm{C}$ for $40 \mathrm{sec}$; final elongation $72^{\circ} \mathrm{C}$ for $5 \mathrm{~min}$. The PCR products obtained were migrated on a $1.5 \%$ agarose gel containing $10 \mu \mathrm{g} / \mathrm{ml}$ of Ethidium Bromide. Migration was performed in a buffer tank filled with TAE buffer containing $40 \mathrm{mM}$ Tris, $20 \mathrm{mM}$ acetic acid, $1 \mathrm{mM}$ EDTA, $\mathrm{pH}=8$ for $20 \mathrm{~min}$ at $120 \mathrm{~V}$ and visualization of the PCR products under a UV lamp connected to a photographic device.

The resulting PCR products from multiple KO mice confirmed the absence of the TAP-L gene and the presence of the Neo cassette (Figure 2B), indicating that the TAP-L gene was deleted as expected and that the mice obtained were TAP-L KO/KO. Consequently, the band recognized by the $\mathrm{ABCB} 9$ antibody, even though 
running at the expected molecular weight, could not correspond to the TAP-L protein.

\section{Conclusion}

Collectively, these results show that the commercial ABCB9 antibody recognizes a protein with a molecular weight similar to that of TAP-L. It is impossible to know whether it also recognizes TAP-L. Our findings highlight the importance of verifying commercial antibody specificity using knockout cells. If such cells are not available, lentiviruses encoding target-specific shRNA, which are now readily available for an essentially complete range of proteins, can be used to produce cells that provide informative negative controls.
Author contributions

ML designed, performed and interpreted experiments and wrote the manuscript. PvE designed and interpreted experiments and edited the manuscript.

Competing interests

Both authors confirm that they have no conflict of interest.

Grant information

Supported by a grant from the Fondation pour la Recherche Médicale (Equipe FRM DEQ20130326539) to PvE.

\section{References}

Bangert I, Tumulka F, Abele R: The lysosomal polypeptide transporter TAPL: more than a housekeeping factor? Biol Chem. 2011; 392(12): 61-66. PubMed Abstract | Publisher Full Text

Demirel O, Waibler Z, Kalinke U, et al:: Identification of a lysosomal peptide transport system induced during dendritic cell development. J Biol Chem. 2007; 282(52): 37836-37843.

PubMed Abstract | Publisher Full Text

Herget M, Kreissig N, Kolbe C, et al:: Purification and reconstitution of the antigen transport complex TAP: a prerequisite for determination of peptide stoichiometry and ATP hydrolysis. J Biol Chem. 2009; 284(49):
33740-33749.

PubMed Abstract | Publisher Full Text | Free Full Text

Inaba K, Inaba M, Romani N, et al.: Generation of large numbers of dendritic cells from mouse bone marrow cultures supplemented with granulocyte/ macrophage colony-stimulating factor. J Exp Med. 1992; 176(6): 1693-702. PubMed Abstract | Publisher Full Text | Free Full Text

Wolters JC, Abele R, Tampé R: Selective and ATP-dependent translocation of peptides by the homodimeric ATP binding cassette transporter TAP-like (ABCB9). J Biol Chem. 2005; 280(25): 23631-23636.

PubMed Abstract | Publisher Full Text 


\section{Open Peer Review}

\section{Current Peer Review Status:

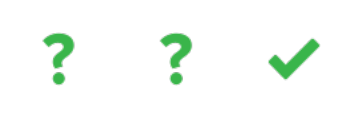

\section{Version 1}

Reviewer Report 29 June 2015

https://doi.org/10.5256/f1000research.7017.r9026

(c) 2015 Raghavan M. This is an open access peer review report distributed under the terms of the Creative Commons Attribution License, which permits unrestricted use, distribution, and reproduction in any medium, provided the original work is properly cited.

\section{Malini Raghavan \\ Department of Microbiology and Immunology, University of Michigan Medical School, MI, USA}

This study relates to antibody specificity for the characterization of ABCB9 (transporter associated with antigen processing-like (TAP-L)) expression. The methods and results are explained in detail and the abstract and title are appropriate for the study. TAP-L knockout/wild type heterozygous mice from a commercial source were crossed to obtain homozygous TAP-L knockout mice. TAP-L deficiency in the knockout is confirmed by PCR. Cell lysates from bone marrow-derived dendritic cells of wild type or TAP-L-deficient mice were subject to immunoblotting analyses with a rabbit polyclonal anti-TAP-L antibody from Abcam (http://www.abcam.com/ABCB9-antibodyab86222.html). An expected band at $84 \mathrm{kDa}$ is seen. However, similar sized bands are seen in lanes containing lysates from either the wild type or the knockout mice, suggesting that the tested antibody is not specific for TAP-L, at least based on immunoblotting analyses. The commercial vendor should take note of this study. The commercial link also indicates immunoprecipitations and immunohistochemistry as tested applications for the antibody. These applications could also be tested using the knockout cells as negative controls. While the study correctly emphasizes the importance of relevant controls prior to the use of commercial antibodies, it appears that a number of TAP-L-specific antibodies are available from different commercial sources. It would be useful to the reader to know which of the commercial antibodies are in fact specific for TAP-L.

Competing Interests: No competing interests were disclosed.

I confirm that I have read this submission and believe that I have an appropriate level of expertise to confirm that it is of an acceptable scientific standard.

Reviewer Report 15 June 2015

https://doi.org/10.5256/f1000research.7017.r8943 
(C) 2015 Momburg F. This is an open access peer review report distributed under the terms of the Creative Commons Attribution License, which permits unrestricted use, distribution, and reproduction in any medium, provided the original work is properly cited.

\section{Frank Momburg}

Department of Translational Immunology, German Cancer Research Center, Heidelberg, Germany

This in an interesting antibody validation article showing that a rabbit polyclonal antibody raised against a peptide (475-525) within the human TAP-L transporter (84 kDa) apparently cross-reacts with another unknown protein of similar size within TAP-L deficient murine dendritic cells. Since mouse TAP-L has a decent homology to TAP2 $(77.5 \mathrm{kDa})$ and TAP1 $(78.9 \mathrm{kDa})$ the authors should precipitate mTAP1/2 and perform a blot with this polyclonal antibody to prove or disprove that the reported cross-reactivity is to TAP.

Please follow this link to view the homology of mTAPL(a.a. 475-525) with mTAP2, and with mTAP1: https://f1 000researchdata.s3.amazonaws.com/supplementary/6535/041aa8a5-5260-4b06-929eb91f6b3c51e9.tif

Competing Interests: No competing interests were disclosed.

I confirm that I have read this submission and believe that I have an appropriate level of expertise to confirm that it is of an acceptable scientific standard, however I have significant reservations, as outlined above.

Reviewer Report 15 June 2015

https://doi.org/10.5256/f1000research.7017.r9028

(C) 2015 Drake J. This is an open access peer review report distributed under the terms of the Creative Commons Attribution License, which permits unrestricted use, distribution, and reproduction in any medium, provided the original work is properly cited.

\section{James Drake}

Center for Immunology and Microbial Disease, Albany Medical College, Albany, NY, USA

In this article, the authors report the results of studies in which they attempt to validate the specificity of a commercially available antibody to TAP-Like (TAP-L), which is an endosomal peptide transporter from the same family at the prototypical ER TAP proteins. They report that, unexpectedly, the anti-TAP-L antibody exhibits immunoreactivity on samples prepared from TAP-L knock mice.

Suggestions for improvement:

It would be helpful to know the number of cell equivalents loaded on each lane of the gels. The gels were loaded for equal protein, so the number of cell equivalents is likely similar, but this point should be addressed.

Figure 1 - Since the purpose of the experiment is to test the specificity of the primary 
western blot antibody (i.e., anti-TAP-L), it would be appropriate to include a control blot that was probed with secondary antibody only. It is possible that the unexpected reactivity on the western blot is due to the secondary antibody (and that the primary antibody is generating no signal). A blot probed with secondary antibody only would address this possibility.

The company makes specific note of the peptide used to generate the reagent under analysis. Therefore, it would be interesting of the authors compared this sequence to the protein sequence in the available databases to see if they could identify candidates for the non-TAP-L protein being recognized by the antibody under analysis.

Competing Interests: No competing interests were disclosed.

I confirm that I have read this submission and believe that I have an appropriate level of expertise to confirm that it is of an acceptable scientific standard, however I have significant reservations, as outlined above.

\section{Comments on this article}

\section{Version 1}

Reader Comment 12 Oct 2016

Anita Bandrowski, University of California, San Diego, USA

Dear authors, this is a very interesting paper, however you list the antibody as Abcam 86222, but the company catalog number is ab86222. Would you be willing to add "Abcam Cat\# ab86222 (your lot number), RRID:AB_1924743" the full citation for this research resource to your paper. The instructions to authors ask that authors consider adding the RRID for all antibody products used. https://f1000research.com/for-authors/article-guidelines/antibody-validation-articles

Competing Interests: No competing interests were disclosed. 
The benefits of publishing with F1000Research:

- Your article is published within days, with no editorial bias

- You can publish traditional articles, null/negative results, case reports, data notes and more

- The peer review process is transparent and collaborative

- Your article is indexed in PubMed after passing peer review

- Dedicated customer support at every stage

For pre-submission enquiries, contact research@f1000.com 